\title{
PENGEMBANGAN MULTIMEDIA INTERAKTIF UNTUK PEMBELAJARAN BERBICARA BAGI SISWA KELAS IV SEKOLAH DASAR
}

\author{
Farida Yufarlina Rosita \\ IAIN Surakarta \\ Email: fyrosita@gmail.com
}

\begin{abstract}
Abstrak
Penelitian ini bertujuan menghasilkan media pembelajaran berbicara untuk siswa kelas IV SD berupa software yang dilengkapi dengan panduan sebagai bahan pendukung dalam mengoperasikan media pembelajaran. Penelitian ini dilaksanakan dengan dua model pengembangan, yaitu model R2D2 dan model Dick and Carey dengan sifat saling melengkapi. Validasi dilakukan oleh tiga ahli dan satu praktisi dalam bidangnya, serta uji coba lapangan kepada siswa untuk mendapatkan produk yang akurat. Poin-poin yang divalidasi adalah isi, penyajian, dan kelayakan bahasa. Nilai terakhir hasil validasi media pembelajaran adalah 87,33\%, sedangkan hasil validasi buku panduan adalah 92,5\%. Berdasarkan kualifikasi yang telah ditentukan, media pembelajaran ini memenuhi kualifikasi nilai 85-100\%. Dengan demikian, dapat disimpulkan bahwa media ini sangat layak digunakan siswa kelas IV SDN 2 Sukosari, Dagangan, Madiun.
\end{abstract}

Kata kunci: pengembangan, media pembelajaran, berbicara

\begin{abstract}
This research was conducted to produce a speaking learning media for fourth grade students in the form of software equipped with the guide as supportive material in operating the media. This research was conducted by using two models: R2D2 and Dick and Carey development models in mutually complementing characteristics. Three points validated in this research are content, performance, and language appropriateness which is conducted by three experts and a practitioner of the field, and proper test to the students to gain the accuracy of the product. The score as the result of media validation is $87,33 \%$, while the guide book validation is $92.5 \%$. Based on the predetermined qualification, this learning media is fulfilling the qualification score of $85-100 \%$. Thus, it can be concluded that this media is appropriate to be used by the fourth grade students of SDN 2 Sukosari, Dagangan, Madiun.
\end{abstract}

Keywords: development, learning media, speaking

\section{PENDAHULUAN}

Berbicara merupakan hal penting karena digunakan sebagai bentuk Komunikasi antarmanusia. Berbicara juga merupakan suatu bentuk yang paling unik karena menyangkut berbagai masalah yang sangat kompleks. Hal ini diperkuat oleh Djiwandono (1996:68) yang menyatakan bahwa berbicara adalah kemampuan yang aktif produktif karena dalam berbicara dituntut prakarsa nyata dalam menggunakan bahasa untuk mengungkapkan diri secara lisan. Selain itu, berbicara sangat penting dalam kehidupan bermasyarakat untuk menyampaikan suatu maksud, belajar dengan orang lain, berbagi pengalaman, bekerja sama, dan meningkatkan kemampuan intelektual dan kesastraan. 
Berbicara bukanlah hal yang sulit jika dilakukan dalam situasi informal, seperti bersenda gurau dan sekedar ngobrol. Namun, keterampilan berbicara dalam forum formal akan terasa sangat sulit dan menjadi masalah besar jika dilakukan pada seseorang yang belum terlatih. Orang yang mahir berbicara pun belum tentu bisa menjadi pembicara yang baik di depan publik.

Pembelajaran berbicara diajarkan sejak siswa duduk di bangku sekolah dasar dengan tujuan agar siswa dapat menyampaikan buah pikiran, gagasan dan ide dengan bahasa yang dapat dipahami orang lain dengan tingkat kebahasaan sesuai dengan karakter umur dan kelompok kelas siswa bersangkutan (Rosita, 2011: 3). Lebih lanjut, Gani (1987:310) menjelaskan bahwa tujuan pembelajaran berbicara adalah untuk menumbuhkan kemampuan siswa untuk berbicara secara lancar dengan menggunakan kalimat dan kosakata yang benar serta tepat sesuai dengan kaidah tata bahasa, tempat, dan situasi. Secara lebih khusus, tujuan pembelajaran berbicara untuk siswa sekolah dasar adalah menumbuhkan penguasaan kemampuan siswa untuk menggunakan struktur serta kosa kata bahasa Indonesia dalam komunikasi yang normal pada suatu pembicaraan di antara penutur-penutur bahasa Indonesia.

Dengan berbicara, segala unek-unek, gagasan, ide, dan pendapat akan tersampaikan. Dengan melatih siswa aktif dalam pembelajaran berbicara, maka akan dihasilkan manusia-manusia unggul dan berhasil di kemudian hari. Akan tetapi, selama ini masih banyak siswa yang belum ikut berperan aktif dalam kegiatan berbicara di kelas, baik untuk mengungkapkan pendapat, bertanya, ataupun menjelaskan kembali pelajaran yang telah diterimanya.
Sebenarnya, kemampuan berbicara siswa sudah cukup baik, namun siswa masih kesulitan dalam mengungkapkan sebuah ide. Hal tersebut karena kurangnya rasa percaya diri dan kurang keberanian dalam berbicara. Siswa lebih sering mengabaikan ketika guru mengajarkan keterampilan berbicara. Hal ini karena siswa menganggap bahwa keterampilan berbicara sangat mudah, sehingga tidak perlu dipelajari dan guru tidak mempunyai materi yang bervariasi dalam mengajarkan keterampilan berbicara.

Penelitian ini bertujuan untuk menghasilkan multimedia interaktif dalam pembelajaran berbicara untuk siswa SD/MI kelas IV yang dikemas dalam CD (compact disc) dalam bentuk software yang berisi materi singkat, contoh, latihan, quiz, dan tugas-tugas berbicara untuk siswa SD kelas IV. Media pembelajaran ini dikembangkan dari segi isi, penyajian, dan kelayakan bahasa. Dari segi ini, indikator media pembelajaran yang dikembangkan adalah (a) kesesuaian media pembelajaran dengan materi, (b) kemudahan isi media pembelajaran, (c) kesesuaian isi media pembelajaran berbicara dengan KD-KD dalam standar isi, (d) kesesuaian isi media pembelajaran berbicara, (e) keaktualan isi media pembelajaran berbicara dilihat dari kebutuhan siswa, (f) kejelasan petunjuk yang menyertai media, dan (g) kemanfaatan media pembelajaran. Dari segi penyajian, indikator media pembelajaran yang dikembangkan yaitu (a) kevariasian materi, (b) ketersediaan pembangkit motivasi, (c) keruntutan dan konsistensi konsep, (d) keotentikan materi, (e) keaktualan contoh-contoh dalam media, (f) kesesuaian sajian media pembelajaran dengan alur berpikir induktif, serta (g) ketersediaan bahan pendukung. Dari segi bahasa, indikator media pembelaran yang dikembangkan adalah (a) kesesuaian penggunaan bahasa, (b) bentuk 
bahasa, (c) kekomunikatifan bahasa, dan

(d) kemudahan penyampaian pesan.

Media pembelajaran ini juga dilengkapi dengan buku panduan untuk guru dalam menerapkan penggunaan media tersebut dalam pembelajaran. Berdasarkan isinya, buku panduan ini disusun dengan kriteria (a) kejelasan petunjuk, (b) penggunaan bahasa dalam buku panduan, (c) kekomunikatifan bahasa, serta (d) tampilan buku panduan.

Multimedia dalam proses belajar mengajar dapat digunakan dalam tiga fungsi. Pertama, multimedia dapat berfungsi sebagai alat bantu instruksional. Kedua, multimedia dapat berfungsi sebagai tutorial interaktif, misalnya dalam simulasi. Ketiga, multimedia dapat berfungsi sebagai sumber petunjuk belajar, misalnya, multimedia digunakan untuk menyimpan serangkaian slide mikroskop atau radiograf (Mardika, 2009:6). Tanpa menggunakan media, proses belajar mengajar tidak dapat berkembang dengan baik, terlebih jika ingin menciptakan pola penyajian yang interaktif. Oleh karena itu, media menjadi saran yang tepat untuk digunakan oleh para pendidik.

Pengembangan media pembelajaran berbicara ini memiliki tujuan untuk memperkaya ilmu pengetahuan, menjadi sumbangan untuk pembelajaran berbicara bahasa Indonesia sebagai usaha memperbaiki mutu pendidikan, menambah pengetahuan, wawasan, pengalaman guru dalam memberikan materi kepada siswa, dan dapat digunakan oleh guru sebagai media utama untuk membantu proses belajar mengajar. Selain itu, media pembelajaran ini bertujuan untuk meningkatkan minat belajar siswa, khususnya dalam belajar berbicara siswa sekolah dasar, serta meningkatkan pemahaman siswa terhadap apa yang telah ia lihat, dengar, dan dipelajari.
Berbicara merupakan kegiatan berbahasa lisan. Dalam berbicara seseorang menyampaikan informasi melalui suara atau bunyi bahasa (Tarigan, dkk, 1986:86). Selain itu, PGMI (2008) menyatakan bahwa berbicara merupakan ungkapan pikiran dan perasaan pikiran seseorang dalam bentuk bunyi-bunyi bahasa. Dengan berbicara, seseorang dapat menyampaikan gagasan, ide, pemikiran, harapan, dan keinginannya. Dua pendapat tersebut pada dasarnya sama saja, yakni berbicara merupakan keterampilan atau kemampuan untuk menyampaikan pesan berupa pikiran, gagasan dan perasaan melalui bahasa lisan kepada orang lain.

Saksomo (1997:2) menjelaskan bahwa berbicara dipandang sebagai suatu bentuk komunikasi lisan, suatu cabang ilmu tentang bahasa lisan, atau suatu aktivitas kebahasaan dengan menggunakan bahasa lisan. Dalam definisi tersebut dapat disimpulkan bahwa berbicara merupakan salah satu aspek keterampilan berbahasa, yaitu aspek lisan produktif (menghasilkan bahasa secara lisan).

Berbicara adalah salah satu proses mengomunikasikan informasi kepada orang lain. Oleh karena itu, berbicara sangat erat hubungannya dengan kebutuhan sosial. Saksomo (1997:24) menjelaskan bahwa tujuan berbicara adalah untuk merealisasikan diri dalam penyesuaian sosial dan pribadinya.

Keterampilan berbicara pada dasarnya harus dimiliki oleh semua orang yang di dalam kegiatannya membutuhkan komunikasi, baik yang bersifat satu maupun dua arah (timbal balik). Seseorang yang memiliki keterampilan berbicara yang baik akan memiliki kemudahan dalam pergaulan, baik di dalam atau di luar rumah. Dengan keterampilannya, segala pesan yang disampaikan akan mudah dicerna, sehingga komunikasi dapat berjalan lancar dengan siapa saja. 
Djiwandono (1996:68) menyatakan bahwa berbicara adalah kemampuan aktifproduktif karena dalam berbicara dituntut prakarsa nyata dalam menggunakan bahasa untuk mengungkapkan diri secara lisan. Keterampilan berbicara pada dasarnya harus dimiliki oleh semua orang yang di dalam kegiatannya membutuhkan komunikasi, baik yang bersifat satu maupun dua arah (timbal balik). Seseorang yang memiliki keterampilan berbicara yang baik akan memiliki kemudahan di dalam pergaulan, baik secara umum atau pribadi, di dalam atau di luar rumah, dan secara formal atau informal. Dengan keterampilann, segala pesan yang disampaikan akan mudah dicerna, sehingga komunikasi dapat berjalan lancar dengan siapa saja. Karena pentingnya berbicara itulah, keterampilan ini sudah harus diajarkan sejak siswa duduk pada pendidikan formal jenjang sekolah dasar.

Gani (1987:310) menjelaskan bahwa tujuan pembelajaran berbicara adalah untuk menumbuhkan kemampuan siswa untuk berbicara secara lancar dengan menggunakan kalimat dan kosakata yang benar serta tepat sesuai dengan kaidah tata bahasa, tempat, dan situasi. Secara lebih khusus, tujuan pembelajaran berbicara untuk siswa sekolah dasar adalah menumbuhkan penguasaan kemampuan siswa untuk menggunakan struktur serta kosa kata bahasa Indonesia dalam komunikasi yang normal pada suatu pembicaraan di antara penutur-penutur bahasa Indonesia.

Dalam pembelajaran, perlu adanya perantara (media) agar dapat digunakan untuk membantu pendidik dalam menjelaskan serta menyampaikan materi pelajaran. Asror (2011:10) mengungkapkan bahwa media pembelajaran adalah segala sesuatu (alat, bahan, atau perangkat) yang digunakan dalam proses pembelajaran untuk menyampaikan pesan atau informasi sehingga dapat merangsang pikiran, perhatian, dan minat siswa demi tercapainya tujuan instruksional. Hal tersebut senada dengan pendapat Santyasa (2007:3) bahwa media pembelajaran merupakan segala sesuatu yang dapat digunakan untuk menyalurkan pesan (bahan pembelajaran), sehingga dapat merangsang perhatian, minat, pikiran, dan perasaan siswa dalam kegiatan belajar untuk mencapai tujuan belajar.

Dalam penelitian ini, dirancang sebuah media pembelajaran yang diharapkan mampu membantu siswa dalam proses pembelajaran, khususnya dalam keterampilan berbicara siswa sekolah dasar. Semakin baik media tersebut dirancang serta digunakan, semakin baik pula media tersebut dalam menjalankan fungsinya sebagai penyalur pesan.

Pembelajaran berbicara untuk siswa sekolah dasar merupakan salah satu hal yang penting. Hal ini dilaksanakan sebagai pembentukan pondasi kepada siswa agar semua hal yang muncul ketika berbicara, seperti keberanian, keluwesan, kelancaran mengungkapkan gagasan, dan kepercayadirian dapat secara otomatis tertanam dalam diri siswa.

Menurut teori perkembangan kognitif yang dikemukakan oleh Piaget, Sunarto dan Hartono (2002:24) menjelaskan bahwa anak usia kelas IV sekolah dasar berada pada tingkat operasional konkret. Pada tingkat ini, seorang anak mulai berpikir rasional. Hal ini menunjukkan bahwa anak memiliki operasi-operasi logis yang dapat diterapkan pada masalah-masalah konkret. Anak juga sudah dapat menentukan halhal yang membuat mereka lebih tertarik kepada beberapa pilihan yang ditawarkan kepada mereka.

Sehubungan dengan hal tersebut, Nurgiyantoro (2005:52) menyatakan bahwa karakteristik anak pada usia 7-11 tahun ada empat. Pertama, anak dapat membuat klasifikasi sederhana, meng- 
klasifikasikan objek berdasarkan sifat-sifat umum, misalnya klasifikasi warna, dan karakter tertentu. Kedua, anak dapat membuat urutan sesuatu secara semestinya, mengurutkan abjad, angka, besar, kecilm dan lain-lain. Ketiga, anak mulai dapat mengembangkan imajinasinya ke masa lalu dan masa depan. Hal ini karena adanya perkembangan pola pikir yang egosentris yang menjadikannya lebih mudah untuk mengidentifikasi sesuatu dengan sudut pandang yang berbeda. Keempat, anak mulai dapat berpikir argumentatif dan memecahkan masalah sederhana. Ada kecenderungan memeroleh ide-ide sebagaimana yang dilakukan oleh orang dewasa, namun belum berpikir tentang sesuatu yang abstrak karena jalan berpikirnya masih terbatas pada situasi yang konkret.

Media pembelajaran yang dikhususkan pada keterampilan berbicara untuk siswa sekolah dasar memiliki karakteristik khusus sesuai dengan karakteristik anak pada usia 7-11 tahun. Karakteristik tersebut diantaranya menggunakan bahasa sederhana, memuat visualisasi yang menarik minat siswa pada usianya, sesuai dengan perkembangan emosi dan intelektual siswa, dirancang dengan warna-warna cerah, dan difokuskan pada keterampilan berbicara secara khusus.

Dasar lain dari pengembangan media pembelajaran berbicara untuk siswa sekolah dasar ini adalah pernyataan yang diungkapkan Sunarto dan Hartono (2002:25) bahwa proses belajar mengajar dapat berhasil dengan baik jika siswa berinteraksi dengan semua alat inderanya. Seorang pendidik berupaya menampilkan semua rangsangan yang dapat diproses dengan berbagai indera. Semakin banyak indera yang digunakan untuk menerima dan mengolah berbagai informasi, semakin besar informasi tersebut dapat dimengerti dan dipertahankan dalam ingatan siswa.

Hal tersebut semakin menguatkan pengembangan media pembelajaran berbicara untuk siswa sekolah dasar ini karena media pembelajaran, khususnya untuk siswa sekolah dasar, akan membuat anak memiliki gambaran yang lebih jelas terhadap materi yang dipelajarinya.

\section{METODE}

Penelitian ini dilaksanakan dengan menggunakan dua model pengembangan. Model pengembangan tersebut adalah model R2D2 (Recursive, Reflective Design and Development) dan model pengembangan Dick and Carey. Dalam penelitian ini, kedua model pengembangan tersebut digabung berdasarkan ciri-ciri dan langkah-langkah yang terdapat pada masing-masing model dengan sifat saling melengkapi.

Prosedur penelitian dan pengembangan dirumuskan dalam beberapa tahapan sesuai dengan model pengembangan R2D2 dan Dick and Carey. Model pengembangan R2D2 memiliki tiga fokus utama, yaitu (a) fokus penetapan (define focus), (b) fokus desain dan pengembangan (design and development focus), dan (c) fokus diseminasi (dissemination focus). Akan tetapi, prosedur yang digunakan dalam penelitian dan pengembangan ini hanya sampai pada fokus desain dan pengembangan (design and development focus). Selain itu, model pengembangan Dick and Carey yang digunakan dalam penelitian ini diadaptasi sesuai kebutuhan pengembangan. Dalam penelitian ini, kegiatan evaluasi formatif dalam model pengembangan Dick and Carey disebut sebagai kegiatan validasi produk. Hal ini digunakan untuk mendapatkan hasil pengembangan yang maksimal. 
Data penelitian ini ada dua macam, yaitu data kualitatif dan kuantitatif. Data kualitatif berupa data identifikasi awal, data hasil validasi dan uji lapangan yang berupa data verbal (catatan, saran, komentar, koreksi, masukan, dan usul langsung) terhadap media pembelajaran yang dikembangkan. Data kuantitatif berupa data hasil validasi atau telaah ahli dan uji lapangan yang berupa angka terhadap produk yang dihasilkan. Kedua jenis data tersebut diperoleh dari para ahli, praktisi, dan siswa.

Pengumpulan data kualitatif dilakukan dengan menggunakan beberapa instrumen, yaitu lembar observasi, lembar wawancara, dan lembar angket. Lembar observasi digunakan sejak awal proses pengembangan, yaitu pada fokus penetapan maupun fokus desain dan pengembangan. Lembar wawancara digunakan sebagai panduan dalam rangka mengumpulkan informasi awal, analisis kebutuhan, dan juga digunakan untuk uji coba lapangan, khusus untuk data verbal seperti saran, masukan, dan usul langsung. Lembar angket digunakan untuk menghimpun data dari para ahli, praktisi (guru), maupun siswa pada kegiatan validasi oleh ahli dan praktisi, serta uji lapangan kepada siswa. Lembar angket ini juga digunakan untuk mengumpulkan data kuantitatif.

Teknik analisis data kualitatif dalam penelitian dan pengembangan ini dilaksanakan secara deskriptif kualitatif dengan langkah-langkah sebagai berikut:

a) mengumpulkan data verbal seperti data identifikasi awal, data analisis kebutuhan siswa, dan data verbal lainnya dari hasil uji validasi oleh ahli dan praktisi dan uji lapangan,

b) mencatat, menghimpun, dan menyeleksi data-data yang telah dikumpulkan,

c) melakukan klarifikasi dan analisis data, dan d) merumuskan hasil analisis tersebut untuk digunakan dalam merevisi media pembelajaran yang dikembangkan.

Data kuantitatif dianalisis secara statistik deskriptif, yaitu untuk data numerikal yang diperoleh dari validasi oleh ahli dan praktisi, serta uji lapangan oleh siswa. Langkah-langkah analisis tersebut adalah sebagai berikut:

a) mengumpulkan data numerikal,

b) mencatat, menghimpun, dan menyeleksi data-data yang telah dikumpulkan,

c) menganalisis data dengan cara memberikan rata-rata nilai, dan

d) menyimpulkan hasil analisis data dalam bentuk persentase seperti pada Tabel 3.1.

Data yang sudah dianalisis tersebut dijadikan acuan untuk merevisi media pembelajaran yang dikembangkan.

Tabel 3.1 Kualifikasi Hasil Validasi Dan Uji Coba

\begin{tabular}{ll}
\hline Persentase & Keterangan \\
\hline $85-100 \%$ & Sangat layak \\
$75-84 \%$ & Layak \\
$55-74 \%$ & Cukup layak dan \\
& $\begin{array}{l}\text { revisi } \\
\text { Tidak layak dan } \\
\text { revisi }\end{array}$ \\
\hline
\end{tabular}

\section{HASIL DAN PEMBAHASAN}

Data ini merupakan data hasil pengembangan yang telah ditelaah oleh para ahli dan praktisi (guru) serta diujicobakan kepada siswa. Data hasil pengembangan meliputi penyajian data, analisis data, dan revisi produk yang berupa angket, saran, masukan, dan atau catatan. Revisi produk digunakan untuk memperbaiki isi media pembelajaran yang kurang sempurna mengacu dari saran ahli/ pakar, guru, dan siswa. 
Dalam penelitian ini, terdapat tiga poin atau aspek yang dinilai atau divalidasi. Aspek-aspek tersebut adalah isi, penyajian, dan kelayakan bahasa pada media pembelajaran dan buku panduan. Berikut adalah data hasil pengembangan media pembelajaran dari masing-masing segi.

\section{Data Hasil Pengembangan Media Pembelajaran dari Aspek Isi}

Isi materi yang dikembangkan mengacu pada standar kompetensi yang sesuai dengan Kurikulum Tingkat Satuan Pendidikan dan disajikan secara bertahap untuk memudahkan siswa belajar secara berkelompok.

Pengembangan isi materi dalam penelitian ini meliputi materi dari kompetensi dasar: (a) mendeskripsikan tempat sesuai dengan denah atau gambar dengan kalimat yang runtut dan (b) menjelaskan petunjuk penggunaan suatu alat dengan bahasa yang baik dan benar.

Analisis data hasil validasi terhadap pakar/ahli dan guru bahasa Indonesia yang diperoleh dari angket mendapatkan penilaian "baik" dan "sangat baik" oleh ahli 1, ahli 2, ahli 3, dan guru. Selain itu, data yang dihimpun dari hasil uji coba terhadap siswa menunjukkan bahwa semua siswa sepakat dengan menjawab "ya" terhadap beberapa aspek, dan terdapat jawaban "tidak” terhadap beberapa aspek yang lain.

Dari keseluruhan data yang diperoleh, dibuktikan bahwa pengembangan media pembelajaran berbicara dari aspek isi masih terdapat kekurangan. Kekurangan tersebut diantaranya belum sempurnanya materi tentang petunjuk berbicara yang baik dan benar. Selain itu, materi belum cukup untuk keterampilan berbicara. Dalam media pembelajaran yang dikembangkan, masih terdapat beberapa materi yang tidak dekat dengan kehidupan sehari-hari siswa.
Selain itu, materi dalam media belum seluruhnya sesuai dengan tingkat perkembangan intelektual dan emosional siswa (cara berpikir, pengetahuan, dan ketertarikan siswa).

\section{Data Hasil Pengembangan Media Pembelajaran dari Aspek Penyajian}

Tuntutan berbicara untuk siswa didesain bervariasi untuk meningkatkan minat belajar siswa dan membuat siswa tidak bosan. Tuntutan berbicara dalam media pembelajaran ini divariasikan dalam beberapa bentuk latihan berkelompok dan individu. Dalam media pembelajaran disediakan pembangkit motivasi berupa ilustrasi, gambar, foto, video, animasi, dan wama-warna yang sesuai dengan jenjang pendidikan SD/MI kelas IV. Foto, ilustrasi, dan gambar disajikan dalam tiap bagian media pembelajaran agar minat siswa dalam mempelajari media pembelajaran ini meningkat.

Media pembelajaran ini juga dilengkapi dengan bagian pendahulu yang memuat materi prasyarat untuk memahami keterampilan berbicara yang disajikan dalam media pembelajaran. Begitu juga dengan dilengkapinya konteks-konteks yang dekat dengan siswa, seperti pengenalan alat-alat, nama tempat, dan kegiatan-kegiatan lainnya. Contoh-contoh dalam media pembelajaran ini juga disesuaikan dengan hal-hal yang konkret, nyata, dan aktual. Pola urutan dan komponen sajian kegiatan belajar dalam media pembelajaran ini juga didesain secara konsisten.

Analisis data pengembangan penya jian media pembelajaran menunjukkan bahwa penyajian yang dikembangkan dalam media pembelajaran berbicara ada yang harus direvisi karena ketersediaan pembangkit motivasi khususnya warnawarna dalam media pembelajaran masih ada yang belum relevan dengan teks atau bagian-bagian dalam media pembelajaran. 
Data Hasil Pengembangan Media Pembelajaran dari Aspek Kelayakan Bahasa

Bahasa dalam media pembelajaran ini dikembangkan sesuai dengan tingkat perkembangan intelektual dan emosional siswa SD/MI kelas IV. Selain itu, terdapat pesan-pesan yang disampaikan kepada siswa yang menggunakan bahasa menarik, jelas, dan tidak menimbulkan makna ganda sehingga siswa dapat memahami pesanpesan tersebut. Pilihan kata yang digunakan dalam media pembelajaran ini disesuaikan dengan kaidah bahasa Indonesia dengan penggunaan ejaan dan tanda baca yang tepat. Kalimat dalam paragraf-paragaf juga disesuaikan dengan tingkat pemahaman siswa sehingga tetap terkesan komunikatif dan tidak bertele-tele agar siswa lebih termotivasi untuk tetap mempelajari media pembelajaran ini.

Dari keseluruhan data yang diperoleh dari kegiatan validasi oleh pakar/ahli dan guru, serta ujicoba kepada siswa, dibuktikan bahwa pengembangan media pembelajaran dari segi kelayakan bahasa terdapat beberapa kekurangan, antara lain (a) terdapat pilihan kata dan kalimat yang tidak sesuai dengan kaidah bahasa, (b) terdapat beberapa bahasa dalam media pembelajaran kurang dapat dipahami oleh siswa, (c) terdapat kata-kata yang sulit dipahami siswa, dan (d) terdapat beberapa paragraf yang terlalu panjang, sehingga kurang mudah dipahami siswa.

\section{Data Hasil Pengembangan Panduan Penggunaan Media Pembelajaran}

Kegiatan validasi terhadap buku panduan oleh pakar/ahli materi dan guru bahasa Indonesia dilakukan dengan mengacu pada beberapa indikator, yaitu (a) kejelasan petunjuk; (b) kesesuaian penggunaan bahasa yang meliputi ejaan, tanda baca, pilihan kata, bentukan kata, struktur kalimat, dan aspek-aspek mekanik lainnya; (c) kekomunikatifan bahasa; dan (d) tampilan buku panduan.

Data kegiatan validasi dan uji coba lapangan, disimpulkan bahwa panduan penggunaan media pembelajaran terdapat beberapa kekurangan, yaitu sampul buku harus menunjukkan isi buku, sehingga gambar yang terdapat dalam sampul harus ada di dalam isi buku. Selain itu, buku panduan sesuai fungsinya sebagai bahan pendukung, tidak diperbolehkan memiliki isi yang lebih lengkap dari bahan utama, termasuk pada sampul belajarnya

Keberadaan media dalam pembelajaran bukanlah suatu hal yang utama. Akan tetapi, media memiliki peran penting dalam keberhasilan pembelajaran. Media pembelajaran dapat berfungsi untuk membangkitkan motivasi belajar dan ketertarikan siswa, mencegah kebosanan siswa dalam proses belajar mengajar, mengefektifkan proses belajar mengajar, dan memperkuat pemahaman siswa (Asnewastri, 2006 :25).

Media pembelajaran merupakan segala sesuatu yang dapat digunakan untuk menyalurkan pesan (bahan pembelajaran), sehingga dapat merangsang perhatian, minat, pikiran, dan perasaan siswa dalam kegiatan belajar untuk mencapai tujuan belajar (Santyasa, 2007:3). Media pembelajaran adalah segala sesuatu (alat, bahan, atau perangkat) yang digunakan dalam proses pembelajaran untuk menyampaikan pesan atau informasi sehingga dapat merangsang pikiran, perhatian, dan minat siswa demi tercapainya tujuan instruksional (Asror, 2011:10). Dari beberapa pengertian tersebut, dapat disimpulkan bahwa media pembelajaran meliputi segala sesuatu yang berfungsi sebagai alat bantu belajar siswa untuk dapat lebih mudah dalam memahami 
pelajaran. Hal tersebut dapat digunakan dalam pembelajaran dengan perantara guru ataupun tidak (dapat dilaksanakan secara mandiri).

Media pembelajaran memiliki jenis yang beragam, mulai yang sederhana, murah sampai dengan yang rumit dan mahal. Media pembelajaran dapat berupa bahan cetak, alat peraga, dan benda-benda yang berada di sekitar siswa. Selain itu media pembelajaran juga terdapat dalam bentuk audio (rekaman, radio, kaset, CD), visual (gambar, foto, maket), audio visual (VCD, film, video), dan multimedia (interaktif, computer based, dan internet).

Adapun media pembelajaran yang dihasilkan dalam penelitian ini berupa multimedia interaktif. Setiyono (2008:13) menjelaskan pengertian multimedia interaktif sebagai media yang dilengkapi dengan alat pengontrol yang dapat dioperasikan oleh pengguna. Interaktif dalam hal ini memiliki pengertian bahwa terjadi komunikasi dua arah atau lebih dari komponen-komponen komunikasi. Komponen komunikasi dalam multimedia interaktif adalah hubungan antara manusia (sebagai user atau pengguna produk) dan komputer (software, aplikasi, atau produk dalam format file). Lebih lanjut Majid (2008:181) memaparkan bahwa media pembelajaran berupa multimedia interaktif telah banyak dimanfaatkan karena di samping menarik juga memudahkan penggunanya dalam mempelajari suatu bidang tertentu.

Sehubungan dengan hal tersebut, media pembelajaran berbicara untuk siswa sekolah dasar yang dihasilkan dalam penelitian ini dapat digunakan karena di dalamnya dilengkapi dengan alat pengontrol yang dapat dioperasikan oleh pengguna sebagai komunikasi dua arah atau lebih dari komponen-komponen komunikasi. Selain itu, media pembelajaran ini dirancang menarik untuk membangkitkan motivasi belajar dan ketertarikan siswa, mencegah kebosanan siswa dalam proses belajar mengajar, dan mengefektifkan proses belajar mengajar.

Dalam pembelajaran, penggunaan media pembelajaran dipilih berdasarkan pertimbangan-pertimbangan tertentu. Menurut Sudjana (1990: 4-5), kriteria yang harus diperhatikan dalam memilih media pembelajaran, yaitu (1) ketepatan media dengan tujuan pengajaran; (2) dukungan terhadap isi bahan pelajaran; (3) kemudahan memperoleh media; (4) keterampilan guru dalam menggunakannya; (5) ketersediaan waktu untuk menggunakannya; dan (6) sesuai dengan taraf berfikir anak. Secara umum, media yang dihasilkan dalam penelitian ini telah dirancang dengan memperhatikan beberapa pertimbangan tersebut, sehingga media pembelajaran ini layak untuk diimplementasikan dalam pembelajaran.

Wujud media pembelajaran yang dihasilkan dalam penelitian ini terdiri atas tiga bagian. Bagian tersebut adalah bagian pendahuluan, isi, dan penutup. Bagian pendahuluan memuat materi prasyarat untuk memahami media pembelajaran utama. Bagian isi dimuat dalam menu latihan dan quiz. Menu ini menuntut siswa untuk dapat mempraktikkan kegiatan berbicara secara langsung. Bagian penutup berisi tugas performansi siswa dalam mempraktikkan kegiatan berbicara sebagai penilaian individu ketercapaian kompetensi siswa.

\section{Pengembangan Media Pembelajaran dari Aspek Isi}

Materi yang dikembangkan dalam media pembelajaran ini diambil dan diperoleh dari berbagai sumber dan telah disesuaikan dengan jenjang pendidikan siswa. Selain itu, materi yang dikembangkan juga dipilih secara tepat. Pemilihan materi yang tepat dan sesuai diharapkan dapat 
memberi kesempatan kepada siswa untuk melakukan eksplorasi pengetahuan, keterampilan, dan sikap melalui berbagai tahapan kegiatan yang memudahkan siswa untuk belajar. Tahapan-tahapan kegiatan dalam media pembelajaran ini meliputi paparan teori dalam menu materi, contohcontoh atau modeling dalam menu latihan, tugas dalam menu quiz, dan performansi dalam menu tugas.

Media pembelajaran berbicara ini dirancang untuk mengondisikan siswa agar dapat belajar secara mandiri dan berkelompok, sehingga siswa dapat dengan mudah memahami dan mempraktikkan materi yang dipelajarinya. Belajar kelompok dalam hal ini adalah belajar dengan orang lain (teman) yang membuat siswa memiliki pandangan lebih luas mengenai suatu hal, sehingga siswa dapat berpikir lebih kritis dalam memahami sebuah materi. Media pembelajaran ini juga menyediakan tempat untuk siswa belajar secara berpasangan pada kegiatan dalam menu quiz. Pada tahapan kegiatan ini, siswa melakukan kegiatan berbicara dan peer assessment. Kegiatan tersebut memiliki maksud agar siswa dapat bekerja sama dengan orang lain. Selain itu, kegiatan ini digunakan juga untuk menguji kejujuran siswa dalam belajar berbicara dan menilai kegiatan berbicara orang lain.

Siswa pada jenjang sekolah dasar memiliki ketertarikan tinggi pada hal-hal baru, termasuk media pembelajaran berupa media audio visual. Cara berpikir siswa pada jenjang ini juga masih sederhana, cara berpikir induktif yang dimulai dari sesuatu yang khusus menjadi lebih luas, dari yang sederhana ke yang lebih rumit. Hal tersebut sesuai dengan yang diungkapkan oleh Nurgiyantoro (2005:52) bahwa anak pada usia 7-11 tahun memiliki kecenderungan memeroleh ide-ide sebagaimana yang dilakukan oleh orang dewasa, namun belum berpikir tentang sesuatu yang abstrak karena jalan berpikirnya masih terbatas pada situasi yang konkret.

\section{Pengembangan Media Pembelajaran dari Aspek Penyajian}

Media pembelajaran disusun dengan tujuan melibatkan siswa untuk lebih aktif dalam pembelajaran dan membantu siswa dalam mencapai penguasaan kompetensi dasar. Ketrampilan berbicara tidak dapat dilatihkan secara maksimal apabila hanya dengan menggunakan materi berbahan cetak. Oleh karena itu, diperlukan materi pendamping berupa contoh berbahasa lisan langsung dalam bentuk media pembelajaran audio visual seperti ini sebagai sarana untuk mengantarkan siswa kepada pencapaian kompetensi.

Dalam media pembelajaran ini, tuntutan yang diberikan kepada siswa disajikan bervariasi agar siswa dapat melakukan kegiatan yang bermanfaat dan tidak monoton. Oleh sebab itu, media pembelajaran memerlukan bahan-bahan pembangkit motivasi agar tujuan dirancangnya media pembelajaran dapat tercapai. Bahan-bahan pembangkit motivasi yang terdapat dalam media pembelajaran yang dihasilkan ini berupa animasi, gambar-gambar, foto, ilustrasi, dan video yang terdapat pada setiap unit.

Media pembelajaran berbicara ini dirancang dengan sistematika penyajian yang runtut. Selain itu, pola urutan kegiatan pada masing-masing unit disusun secara konsisten. Dalam media ini, paparan teori dijadikan bagian pendahulu sebagai materi prasyarat untuk memahami media pembelajaran utama yang disajikan selanjutnya.

Menurut teori perkembangan kognitif yang dikemukakan oleh Piaget, Sunarto 
dan Hartono (2002:24) menjelaskan bahwa anak usia kelas IV sekolah dasar berada pada tingkat operasional konkret. Pada tingkat ini, seorang anak mulai berpikir rasional. Hal ini menunjukkan bahwa anak memiliki operasi-operasi logis yang dapat diterapkan pada masalah-masalah konkret. Anak usia ini masih memiliki alur berpikir induktif. Alur berpikir induktif memiliki pengertian bahwa pola atau alur berpikir yang digunakan yaitu memahami hal-hal yang bersifat khusus, kemudian disimpulkan kedalam hal-hal yang umum. Selain itu, media pembelajaran dirancang sesuai dengan konteks yang dekat dengan siswa pada setiap bagian untuk memudahkan pemahaman siswa.

\section{Pengembangan Media Pembelajaran dari Aspek Kelayakan Bahasa}

Bahasa yang digunakan dalam media pembelajaran ini terdiri atas kesesuaian bahasa dengan tingkat perkembangan intelektual siswa, kesesuaian bahasa dengan tingkat emosional siswa, pesan yang disampaikan kepada siswa, ketepatan penggunaan ejaan dan tanda baca, kesesuaian pilihan kata dengan kaidah bahasa Indonesia yang benar, penyusunan paragraf, kekomunikatifan bahasa, dan grafika yang ditampilkan dalam media pembelajaran.

Seorang anak memiliki beberapa tahap perkembangan aspek kejiwaan. Tahap pekembangan tersebut adalah tahap perkembangan intelektual, perkembangan moral, perkembangan emosional, dan perkembangan bahasa (Nurgiyantoro, 2005:51). Menurut Kurniawan (2009:40), berdasarkan perkembangan intelektual, anak pada rentang usia 7-11 tahun berada pada tahap operasional berpikir konkret. Pada masa usia ini, anak sudah memiliki kemampuan untuk menguasai keterampilan berbahasa yaitu menyimak, berbicara, membaca, dan menulis. Hal tersebut menunjukkan bahwa anak pada usia ini sudah menguasai bahasa dengan lengkap sesuai dengan kemampuan berpikirnya. Selain itu, sesuai dengan perkembangan bahasanya, anak sudah dapat berbicara lancar. Mereka tidak lagi pada tahap memahami kalimat, tetapi sudah pada tahap memahami makna dari kalimat, bahkan teks secara keseluruhan.

Dalam media pembelajaran ini, bahasa yang digunakan bersifat komunikatif agar membuat siswa dapat mengenal selangkah lebih jauh terhadap media pembelajaran tersebut. Dengan demikian, siswa akan dekat dan menyukai media pembelajaran ini sebagai sarana penguasaan kompetensi pembelajaran. Hal tersebut sesuai dengan pernyataan Zhuldyn (2012) bahwa pembelajaran yang optimal memerlukan bahasa yang komunikatif yang memungkinkan semua pihak yang terlibat dalam interaksi belajar mengajar dapat berperan secara aktif dan produktif.

\section{Pengembangan Panduan Penggunaan Media Pembelajaran}

Petunjuk penggunaan yang terdapat dalam buku panduan ini memuat langkahlangkah menggunakan media pembelajaran keterampilan berbicara. Petunjuk penggunaan juga diberikan pada tiap langkah dalam tahapan pembelajaran. Hal tersebut bertujuan agar media pembelajaran dapat digunakan dengan baik sesuai dengan langkah-langkah yang telah ditentukan.

Sesuai dengan fungsinya sebagai buku panduan, buku ini memuat panduan atau aturan-aturan dalam menjalankan media pembelajaran. Selain itu, buku ini juga memuat rambu-rambu jawaban yang digunakan oleh siswa dalam tahapan kegiatan yang terdapat dalam media. Hal- 
hal tersebut menunjukkan bahwa petunjuk dalam buku panduan ini jelas dan dapat dimanfaatkan secara maksimal dalam mengoperasikan media.

Dalam buku panduan ini, penggunaan sarana-sarana tatabahasa digunakan dengan tepat. Selain itu, kosakata, pola tatabahasa, dan struktur kalimat yang digunakan dalam buku panduan ini dipilih secara saksama dan mengacu pada kaidah-kaidah atau aturan-aturan penulisan agar tulisan dapat dipahami dengan mudah oleh pembaca.

\section{SIMPULAN}

Berdasarkan penelitian yang telah dilaksanakan, terdapat beberapa kesimpulan. Pertama, dengan menggunakan multimedia interaktif ini, pembelajaran di kelas menjadi lebih efektif, bermakna, dan siswa dapat lebih berperan aktif dalam pembelajaran berbicara. Kedua, multimedia interaktif seperti ini dapat diaplikasikan ke dalam semua kondisi kelas agar pembelajaran dapat berjalan lebih efektif dan menarik. Ketiga, multimedia interaktif ini dapat dimanfaatkan oleh semua guru agar membantu dalam pelaksanaan pembelajaran. Keempat, multimedia interaktif dapat dikembangkan lebih lanjut karena metode ini dapat mengaktifkan kelas dan membuat pembelajaran menjadi semakin menarik dan bermakna.

Pengembangan media pembelajaran lebih lanjut juga dapat dilakukan oleh guru melalui forum MGMP. Guru adalah pihak yang memahami betul kebutuhan dalam bidang belajar mengajar. Oleh karena itu, guru dapat mengembangkan media pembelajaran yang sesuai dengan kebutuhan siswa, sehingga tujuan pembelajaran dapat tercapai dengan baik.

\section{DAFTAR PUSTAKA}

Asror, M. Bisrul. 2011. Pengembangan Media Pembelajaran Audio Visual pada Pokok Bahasan Laporan Keuangan Perusahaan Jasa di SMA Negeri 3 Blitar. Skripsi tidak diterbitkan. Malang: Fakultas Ekonomi. Universitas Negeri Malang. Asnewastri. 2006. Keefektifan Penggunaan Media Pembelajaran dalam Meningkatkan Prestasi Belajar Siswa pada Mata Pelajaran Sejarah. “Jurnal Ilmu Pendidikan”. Ditulis dalam http:/ /isjd.pdii.lipi.go.id/admin/jurnal/ Ed3082426.pdf; diakses 5 Desember 2012.

Djiwandono, M. Soenardi. 1996. Tes Bahasa dalam Pengajaran. Bandung: ITB Bandung.

Gani, Zainal A. 1987. Pengajaran Bahasa Indonesia di Sekolah Dasar. Jakarta: Pusat Pembinaan dan Pengembangan Bahasa.

Kurniawan, Heru. 2009. Sastra Anak dalam Kajian Strukturalisme, Sosiologi, Semiotika, Hingga Penulisan Kreatif. Yogyakarta: Graha Ilmu.

Majid, Abdul. 2008. Perencanaan Pembelajaran: Mengembangkan Standar Kompetensi Guru. Bandung: PT Remaja Rosdakarya.

Mardika, I Nyoman. 2009. Pengembangan Multimedia dalam Pembelajaran Kosakata Bahasa Inggris di SD. "Jurnal Ilmu Pendidikan”. Ditulis dalam http:// mardikanyom. tripod.com/Multimedia. pdf; diakses 1 Desember 2012.

Nurgiyantoro, Burhan. 2005. Sastra Anak: Pengantar Pemahaman Dunia Anak. Yogyakarta: Gadjah Mada University Press.

Rosita, Farida Yufarlina. 2011. Pengembangan Bahan Ajar Keterampilan Berbicara Bahasa Indonesia untuk Siswa SD/MI Kelas 
IV Berbasis Cooperative Learning. Skripsi tidak diterbitkan. Fakultas Sastra. Universitas Negeri Malang. Saksomo, Nur. 1997. Kemampuan Berbicara sebagai Wahana Kominukasi. Jakarta: Yayasan Obor. Santyasa, I Wayan. 2007. Landasan Konseptual Media Pembelajaran. Makalah disajikan dalam Workshop Media Pembelajaran bagi Guru-guru SMA Negeri Banjar Angkan, Banjar Angktdan Klungkung, 10 Januari.

Setiyono. 2008. Pengembangan Pembelajaran dengan Menggunakan Multimedia Interaktif untuk Pembelajaran yang Berkualitas. Karya Tulis Ilmiah tidak diterbitkan. Madiun: SMP Negeri 1 Dagangan.

Sudjana, Nana \& Rivai Ahmad. 1990. Media Pengajaran. Bandung: Sinar Baru Algesindo.

Sunarto dan Hartono, Agung. 2002. Perkembangan Peserta Didik. Jakarta: Penerbit Rineka Cipta.

Tarigan, Henry Guntur. 1986. Membaca sebagai Suatu Keterampilan Berbahasa. Bandung: Angkasa.

Zhuldyn. 2012. "Perkembangan Bahasa Anak SD”. Ditulis dalam http:// zhuldyn.wordpress.com/materii-lain/ perkembangan-peserta-didik/ perkembangan-bahasa-anak-sd/; diakses 4 Juni 2013. 